\title{
DYNAMIC HIP SCREW IN FRACTURES OF THE PROXIMAL FEMUR
}

\author{
Deepak Kumar1, Kanwarjeet Singh Saluja ${ }^{2}$ \\ ${ }^{1}$ Assistant Professor, Department of Orthopaedics, Rama Medical College Hospital \& Research Centre, Mandhana, Kanpur. \\ ${ }^{2}$ Senior Resident, Department of Orthopaedics, Rama Medical College Hospital \& Research Centre, Mandhana, Kanpur.
}

ABSTRACT

\section{BACKGROUND}

Sixty consecutive patients with fracture of the proximal femur (41 trochanteric and 19 displaced fracture neck of the femur) were treated by dynamic hip screw implant system using 135-degree plate. Age of the patients varied from 23-96 years. There was one death due to concomitant medical problem, unrelated to surgical procedure and 2 superficial wound infections in the whole series. Union was achieved in all patients and there was no implant failure. Early mobilization and weight bearing contributed in achieving $88.1 \%$ excellent, $8.4 \%$ good and 3.4\% poor end results. By restoring the function of the injured hip, early DHS allows patient the freedom of sitting cross-legged and squatting postures, which are essential part of daily activities of life of most of the Asian countries. Further, it minimizes the hospital stay and follow-up visits of the patients, thereby ensures substantial savings for both the patients and the orthopaedic service.

\section{KEYWORDS}

Dynamic Hip Screw, Poximal Femur.

HOW TO CITE THIS ARTICLE: Kumar D, Saluja KS. Dynamic hip screw in fractures of the proximal femur. J. Evolution Med. Dent. Sci. 2016;5(21):1093-1095, DOI: 10.14260/jemds/2016/253

\section{INTRODUCTION}

The rising number of elderly patients with fractures of the proximal femur and long hospital stay has been prime concern of orthopaedic surgeons round the globe, operative treatment of hip fractures is far superior to the conservative treatment as it reduces mortality and morbidity, simplifies nursing care and thus facilitates early rehabilitation of the patient, provided secure osteosynthesis can be obtained at the time of surgery. The postoperative management of hip fractures in elderly should include early mobilization with full weight bearing to achieve good results.

Various methods have been described for the internal fixation of trochanteric fractures, since the introduction of the stainless steel one piece angled V-nail plate by Capener and the subsequent adoption of the Jewett nail plate in the midseventies. But three problems were frequently encountered: Failure of fixation often requiring reoperation; Inadequate stabilization delaying mobilization and discharge from hospital; and Uncertain fixation requiring prolonged outpatient follow-up (Heyse-Moore et al. 1983) ${ }^{1}$. Stabilization of trochanteric fractures with AO/ASIF angled blade plate is a technically demanding procedure. Also the infection rate and implant complications are high (Regazzoni et al. 1985). ${ }^{2}$

Although, the use of Ender's nails for trochanteric fractures is technically easy procedure, but the problem with this type of fixation is that unstable fractures cannot be sufficiently stabilized to allow immediate weight bearing. Implant complications are also high, if unstable fractures are mobilized with full weight bearing malrotation of the thigh (External rotation) is very frequent, causing problems at the knee joint (Regazzoni et at. 1985 and Roa et al. 1990). ${ }^{3}$ Early mobilization and full weight bearing put great demands on both the implant and the osteoporotic bone.

Financial or Other, Competing Interest: None.

Submission 18-01-2016, Peer Review 13-02-2016,

Acceptance 19-02-2016, Published 12-03-2016.

Corresponding Author:

Deepak Kumar,

97 ' $E$ ', Mandir Road, Panki,

Kanpur-208020.

E-mail: dkortho212@gmail.com

DOI: $10.14260 /$ jemds $/ 2016 / 253$
Because very elderly patients start full weight bearing immediately despite repeated instructions against it, the dynamic hip screw is the favoured implant (Muller et al. 1991). ${ }^{4}$ Dynamic Hip Screw (DHS) is a lag screw, which is biomechanically superior to various compression hip screw systems developed during recent years (Regazzoni 1985). The sliding mechanism secures interfragmentary contact even if resorption of the fracture ends should occur (Svenningsen et al. 1984). ${ }^{5}$ Sitting cross-legged and squatting postures form the essential part of the social and cultural aspects of life of the people living in most Asian countries.

\section{MATERIAL AND METHODS}

In this study, 60 consecutive patients with fractures of the proximal femur were treated using AO/ASIF DHS implant system. Trochanteric fractures (Group A) were classified into stable and unstable (Pruthi et al. 1984). ${ }^{6}$ and fractures of neck of femur (Group B) were classified into undisplaced and displaced (Garden 1961). ${ }^{7}$ In all patients, below knee skin traction was applied to injured limb on admission until the day of surgery. Surgery was performed under spinal/general anaesthesia within 1-5 days (mean 3 days) from the day of admission using DHS implant system ranging from 70-100 $\mathrm{mm}$ size with 4 to 5 hole 135-degree plate. Closed suction drains were removed after 48 hours and patients mobilized out of bed and weight bearing allowed as and when tolerated using walking frame or crutches. Due to general senile changes, two patients had been bed ridden in Group A prior to injury. Sutures were removed between 12-14 days and patients discharged between 2-3 weeks.

They were reviewed at regular intervals for clinical and radiological assessment. The clinical evaluation included assessment of pain, tenderness, movements of the hip, sitting cross-legged and squatting postures and the gait. At the end of 6 months' patients were graded as excellent, good and poor as per the criteria of Kyle (1979). ${ }^{8}$ which we modified as below:

\section{Excellent}

No pain, Minimum limp, Normal range of motion, Can walk without support, Can squat and sit cross-legged. 


\section{Good}

Occasional mild pain, Noticeable limp, Normal range of motion, Can walk with the help of a cane, Can Squat and sit cross-legged.

\section{Poor}

Moderate pain, Marked limp, Limited range of motion, Cannot walk, Cannot squat or Sit cross-legged.

\section{OBSERVATION}

The total number of patients in this study was 60 . Out of 41 intertrochanteric fractures (Group A), 13 were stable and 28 unstable fractures, while all 19 fractures in Group B were transcervical (Garden Stage 3 and 4). The distribution of age, sex and side involved is shown in Table 1 and 2.

\begin{tabular}{|c|c|c|c|c|c|}
\hline \multirow{2}{*}{$\begin{array}{c}\text { Fracture } \\
\text { Type }\end{array}$} & \multirow{2}{*}{$\begin{array}{c}\text { Total } \\
\text { No. of } \\
\text { Patients }\end{array}$} & \multicolumn{2}{|c|}{$\begin{array}{c}\text { Age in } \\
\text { Years }\end{array}$} & \multicolumn{2}{|c|}{ Sex } \\
\cline { 3 - 7 } & Mean & Range & M & F \\
\hline $\begin{array}{c}\text { Trochanteric facture } \\
\text { Group - A }\end{array}$ & 41 & 75.5 & $23-96$ & 22 & 19 \\
\hline $\begin{array}{c}\text { Fracture neck of } \\
\text { femur Group - B }\end{array}$ & 19 & 64.7 & 38.85 & 8 & 11 \\
\hline \multicolumn{3}{|c|}{ Table 1: Patient Profile } \\
\hline
\end{tabular}

\begin{tabular}{|c|c|c|c|c|c|c|}
\hline \multirow{2}{*}{$\begin{array}{c}\text { Fracture } \\
\text { Type }\end{array}$} & $\begin{array}{c}\text { Total } \\
\text { No. of } \\
\text { Patiens }\end{array}$ & \multicolumn{2}{c|}{$\begin{array}{c}\text { Age in } \\
\text { Years }\end{array}$} & \multicolumn{2}{c|}{ Sex } \\
\cline { 4 - 7 } & & Mean & Range & M & F \\
\hline $\begin{array}{c}\text { Tro- } \\
\text { chanteric } \\
\text { facture } \\
\text { (Group A) }\end{array}$ & Stable & 13 & 77.6 & $53-86$ & 6 & 7 \\
\cline { 4 - 8 } & Unstable & 28 & 77.2 & $23-95$ & 16 & 12 \\
\hline $\begin{array}{c}\text { Fracture } \\
\text { neck of } \\
\text { femur } \\
\text { (Group B) }\end{array}$ & $\begin{array}{c}\text { Trans- } \\
\text { cervical }\end{array}$ & 19 & 64.7 & $38-85$ & 8 & 11 \\
\hline \multicolumn{7}{|c|}{ Table 2: Type of Fracture } \\
\hline \multicolumn{7}{|c|}{}
\end{tabular}

Forty patients had domestic accidents (Fall) and one patient was involved in Road Traffic Accident (RTA) in Group A. In Group B, all 19 patients had history of fall at home. In Group A, only one patient of RTA had associated injury in the form of haemoperitoneum (Liver and splenic tears). No one in the Group B had any associated injury. In Group A 31 patients and in Group B 5 patients had associated illness in the form of hypertension, ischaemic heart disease, chronic bronchitis, obesity, diabetes mellitus, ankylosed contralateral hip, benign hyperplasia of prostate and parkinsonism. Average operation time was 75 minutes (60-90 minutes). Patients in both groups were mobilized out of bed on the 2 nd postoperative day. The average hospital stay was three weeks in Group A and two weeks in Group B. Two patients who were bed ridden preoperatively, remained so postoperatively as well. Radiological assessment in the immediate postoperative period at three weeks, six weeks, three months and six months revealed implant was in position in both groups.

Fracture union was seen in three months in Group A and in six months in Group B. Postoperative complications varied in Group A and B. One death in Group A was as a result of concomitant medical problem (Table 3). Postoperative discomfort of pain around the hip persisted in all patients up to 1-2 weeks, then slowly disappeared as the patient started progressively mobilizing and weight bearing. All time patients could sit cross-legged and squat by 6 weeks except two patients where pain increased around the hip and they could not sit cross-legged or squat. These two patients continued to be bed ridden as before the operation, while 5 patients were mobile and could sit cross-legged and squat freely, but experienced some pain in the hip region on walking and resorted to the use of cane.

Final results at six months were evaluated in fifty-nine patients only, as one patient in Group A died on the first postoperative day (Table 4).

\begin{tabular}{|c|c|c|}
\hline & $\begin{array}{c}\text { Trochanteric } \\
\text { Fracture } \\
\text { (Group A) } \\
\end{array}$ & $\begin{array}{c}\text { Fracture Neck of } \\
\text { Femur } \\
\text { (Group B) }\end{array}$ \\
\hline $\begin{array}{l}\text { Deep vein } \\
\text { thrombosis }\end{array}$ & - & 1 \\
\hline Bronchopneumonia & 2 & 1 \\
\hline $\begin{array}{l}\text { Superficial wound } \\
\text { infection }\end{array}$ & 2 & - \\
\hline Swelling of leg & 19 & 3 \\
\hline Pressure sore & 1 & - \\
\hline Death & 1 & - \\
\hline
\end{tabular}

\begin{tabular}{|c|c|c|c|c|}
\hline $\begin{array}{c}\text { Fracture } \\
\text { Type }\end{array}$ & $\begin{array}{c}\text { No. of } \\
\text { Patients }\end{array}$ & Excellent & Good & Poor \\
\hline $\begin{array}{c}\text { Trochanteric } \\
\text { fracture } \\
\text { (Group A) }\end{array}$ & 40 & 36 & 3 & 1 \\
\hline $\begin{array}{c}\text { Fracture neck } \\
\text { of femur } \\
\text { (Group B) }\end{array}$ & 19 & 16 & 2 & 1 \\
\hline Total & $\mathbf{5 9}$ & $\mathbf{5 2}$ & $\mathbf{5}$ & $\mathbf{2}$ \\
\hline \multicolumn{5}{|c|}{ Table 4: Final Results } \\
\hline
\end{tabular}

\section{DISCUSSION}

As regard age, sex, nature of trauma, this series correlates with other published studies (Ganz et al. 1979.9 Svenningsen et al. 1984 and Bridle et al. 1991.10). The number of unstable trochanteric fractures was higher than the stable ones in several studies (Laskin et al. 1979.11 Sverniingsen et al. 1984 and Pruthi et al. 1984). While the number of displaced femoral neck fractures was markedly high in other studies (Brown et al. 1964.12 Ort et al. 1984 and Svenningsen et al. 1984). This series had similar observations as mentioned above.

Operative treatment must provide a stable and strong fixation as many elderly patients are unable to even partially restrict weight bearing (Ganz et al. 1979). DHS allows nor only fixation of anatomically reduced trochanteric fracture but also a guided collapse and impaction of the fragments in the unstable fracture. The screw will slide distally and laterally until a new area of bony support is reached. The implant will therefore act as a load-sharing instead of loadbearing device and the fracture will usually unite. By this "Impaction" the implant failure due to metal fatigue and nail migration are prevented in most instances (Regazzoni et al. 1985). In our series, no such complication was noted. The use of DHS in the treatment of the trochanteric fractures is suitable, as it accommodates the natural tendency of these fractures to collapse (Bannister et al. 1990).13

Up to $75 \%$ of the load in weight bearing can be taken up by the bone fragments in contact at the fracture site and the rest has to be provided by the nail. Early weight bearing then 
can be prescribed even in unstable fractures in the majority of patients without risk of complications attributed to inadequate fixation (Kyle et al. 1979).

In our series, patients were mobilized and immediate weight bearing allowed.

Non-union of an internally fixed intertrochanteric fracture is an uncommon occurrence. But four cases of intertrochanteric fracture non-union and $11 \%$ non-union in displaced fracture neck of the femur with compression screw and $25 \%$ with nail plate have been reported (Laskin et al. 1979 and Svenningsen et al. 1984).

No non-union occurred in this series. There was a mortality rate of $2.4 \%$ (Group A) in this series compared to $19 \%$ in the study of Bridle et al. (1991). Hospital stay for the patients of this series was 2-3 weeks. This period is comparable with other (Ganz et al. 1979 and Svenningsen et al. 1984). Laskin et al. (1979) reported that $76 \%$ of their patients who ambulated before their fracture walked again after surgery. In present series, 57 patients were ambulant before injury. All of them walked in the same manner, 6 months after surgery; $10 \%$ to $15 \%$ of patients with fracture neck of the femur will develop complications (Sisk 1987).14

Surgery may significantly influence the incidence of non-union by using a lag screw, which is connected to a side plate secured to the upper femoral shaft, though the effect of the device on the incidence of avascular necrosis is not completely understood (Ort et al. 1984.15 and Sisk 1987). Since the number of cases of displaced femoral neck fractures in which DHS implant system was used was too small to draw definite conclusions, but on the basis of comparative study of various implant systems for osteosynthesis of fracture of the proximal femur it can be said that DHS is the optimal implant for stabilization of all types of trochanteric fractures including those with subtrochanteric extension and selected fractures of the femoral neck. The operation is relatively easy, suitable for all fracture types, allows early weight bearing and has an acceptable complication rate.

\section{REFERENCES}

1. Heyse-Moore GH, MacEachern AG, Evans DC. Treatment of trochanteric fractures of the femur - a comparison of the Richards screw plate with Jewett nail-plate. J Bone Jt Surg 1983;65(3):262-67.
2. Regazzoni P, Ruedi T, Winqulst R, et al. The dynamic hip screw implant system. Berlin: Springer-Verlag 1985.

3. Roa J, Hambly M. king J, et al. A comparative analysis of Ender's-rod and compression screw and side plate fixation on intertrochanteric fractures of the hip. Clin Orthop 1990;256:125-31.

4. Muller ME, Allgower M, Schneider R, et al. Manual of internal fixation. Berlin Springer - Verlag 1991;3rd edition.

5. Suenningsen S, Benum P, Nesse O, et al. Internal fixation of femoral neck fractures. Acta Orthop Scand 1984;55:423-29.

6. Pruthi KK, Vyas ON, Kuamr S. Condylocephalic fixation of trochanteric fractures with an improvised nail. Indian J Orthop 1984;18(1):25-29.

7. Garden RS. Low angle fixation in fractures of the femoral neck. J Bone Jt Surg 1961;43:647-63.

8. Kyle RF, Gustilo RB, Premer RF. Analysis of 622 intertrochanteric hip fractures. J Bone Jt Surg 1979;61(2):216-221.

9. Ganz R, Thomas Rj, CP Hammerle. Trochanteric fractures of the femur - treatment and results. Clin Orthop 1979;138:30-40.

10. Bridle SH, Patel AD, M Bircher, et al. Fixation of intertrochanteric fractures of the femur - a randomized prospective comparison of the gamma nail and the dynamic hip screw. J Bone Jt Surg 1991;73(2):330-34.

11. Laskin RS, Gruber MA, Zimmerman AJ. Intertrochan fractures of the hip in the elderly - a retrospective analysis of 236 cases. Clin Orthop 1979;141:188-95.

12. Brown JT, Abrami G. Transcervical femoral fracture. A review of 195 patients treated by sliding nail-plate fixation. J Bone Joint Surg Br 1964;46(4):648-63.

13. Bannister GC, Gibson AG, Ackroyd CE, et al. The fixation and prognosis of trochanteric fractures - a randomized prospective controlled trial. Clin Onhop 1990;254:24246.

14. Sisk TD. Fractures of hip and pelvis-Campbell's operative orthopaedics, St Louis etc CV Mosby CO 1987; $7^{\text {th }}$ edition:1719-46.

15. Ort PJ, LaMoat. Treatment of femoral neck fractures with a sliding compression screw and two Knowles pins. Clin Otlhop 1984;190:158-62. 